\title{
Identifying priority conservation areas for above-ground carbon sequestration in Central Mexico
}

\author{
Carmina Cruz-Huerta, \\ Manuel De Jesús González- \\ Guillén, \\ Tomás Martínez-Trinidad, \\ Miguel Escalona-Maurice
}

\begin{abstract}
Identifying forest ecosystems with significant ecological, social, and/or economic values is an important first-step in conserving landscape function. Here, we identify priority conservation areas in the municipalities of Chignahuapan and Zacatlan, Puebla (Mexico), based on: (i) their capacity to sequester atmospheric $\mathrm{CO}_{2}$; and (ii) risk of future deforestation. We also explore management strategies for priority-lands conservation in the Mexican context. Aboveground $C$ sequestration was estimated using wood density and biomass expansion-factor data available from local forestry sources. Deforestation risk was estimated by a probabilistic model of land use change using socioeconomic and biophysical variables. Carbon sequestration estimates ranged from 14 to 531 $\mathrm{Mg} \mathrm{ha}^{-1}$ for Chignahuapan and Zacatlan, respectively. An estimated 11,746 and 4,406 ha of forest was determined to be at risk of deforestation in each municipality. Of these at-risk lands, 2,421 and 1,798 ha were determined to be at high risk. In combination, we determined that 10,687 and 4,319 ha, respectively, are priority lands for carbon sequestration in Chignahuapan and Zacatlan, of which 628 and 310 ha were determined to have high conservation priority. Identifying priority conservation areas through the integrated assessment of carbon sequestration and deforestation risk can enhance efforts to target land management strategies to mitigate climate change impacts. This approach can serve as a model for other forested regions in Mexico and other countries.
\end{abstract}

Keywords: Forest Carbon Sinks, REDD, Climate Change, Deforestation Risk, Priority Conservation, Probabilistic Model, Land Use, Development of carbon absorbed by forests and other natural carbon sinks (Caballero et al. 2007).

Mexico emits more than 553 million tons per year of greenhouse gases (GHG) as a result of industry, farming, and forest degradation and deforestation. This total represents $1.5 \%$ of global emissions. Of this, degradation and deforestation account for $12.4 \%$ of Mexico's total GHG emissions. In response, Mexico pledged in 2009 to limit 2050 GHG emissions to $50 \%$ of year 2000 emissions through its newly established Special Climate Change Program or PECC, for its Spanish acronym (IICA 2012).

To reduce emissions, governmental and non-governmental institutions initiated various measures, such as sustainable forest management, Reducing Emissions from
Colegio de Postgraduados, Carretera México-Texcoco Km. 36.5, Montecillo, Edo. de México, C.P. 56230 (Mexico)

@ Manuel De Jesús González-Guillén (mgonzalezg60@gmail.com)

Received: Jan 12, 2016 - Accepted: Sep 08, 2017

Citation: Cruz-Huerta C, González-Guillén MJ, Martínez-Trinidad T, Escalona-Maurice M (2017). Identifying priority conservation areas for above-ground carbon sequestration in Central Mexico. iForest 10: 923-929. - doi: 10.3832/ifor1980-010 [online 2017-12-07]
Deforestation and forest Degradation (REDD) pilot projects, payment for environmental services, wildlife management units, protected natural areas in forest ecosystems, sustainable planned grazing, and commercial forest plantations (Greenpeace Mexico 2010, CONAFOR 2011, 2014).

To optimize resources and ensure effectiveness, a strategic forest planning approach is needed to identify and protect forested areas with high carbon sequestration (García \& Lagares 2011). These priority conservation areas are spatial representations of the territory defined by environmental, social and cultural characteristics whose presence is threatened by human activities, natural causes, or both (Collins et al. 2001, Morgan et al. 2005). The designation of priority conservation areas for carbon sequestration have already been used to promote the reduction of high rates of deforestation and restore degraded areas (Saavedra et al. 2011, Alvarez \& Rubio 2013) - a strategy that arose from collaboration between foreign research groups and Mexican researchers (Cantú et al. 2004, Riemann \& Ezcurra 2005).

Here, we develop an integrated methodology to quantify both existing forest-level carbon sequestration, and risk of deforestation. This combination is then used to identify priority conservation areas for natural resource protection. 


\section{Materials and methods}

Our research comprised three stages: (1) determining carbon sequestration; (2) estimating risk of deforestation; and (3) delineation and comparative analysis of priority conservation areas for carbon sequestration. We focus on the Chignahuapan-Zacatlan region because it represents the primary forest area of the Sierra Norte mountain range of the State of Puebla (Mexico).

\section{Study area}

The municipalities of Chignahuapan and Zacatlan are located in the Sierra Norte de Puebla, a mountainous, upland region of Central Mexico (19 $39^{\prime} 42^{\prime \prime}-20^{\circ} 08^{\prime} 12^{\prime \prime} \mathrm{N}$ and $\left.97^{\circ} 51^{\prime} 06^{\prime \prime}-98^{\circ} 18^{\prime} 06^{\prime \prime} \mathrm{W}\right)$. The 1250 $\mathrm{km}^{2}$ study area is part of the Trans-Mexican volcanic belt composed of rugged mountain ranges with some intermediate plains. Peaks range from 2300 to $4200 \mathrm{~m}$. The study area has a cold, temperate climate, with annual precipitation ranging from 600 to $1500 \mathrm{~mm}$ (Cruz-Huerta et al. 2015). The region is dominated by pine-oak forests, with $27.2 \%$ covered by coniferous forests.

The combined population in both municipalities is 115,456 inhabitants, of which $15 \%$ belong to an ethnic indigenous group that generally reside within areas of mountainous forest. The two municipalities include 289 discrete settlements, of which five are considered urban areas. The marginalization and human development indices for the study area are 0.16 and 0.74 , respectively, indicating limited social capital and opportunities, and low levels of education, income, and life expectancy (CONAPO 2010). For comparison, at the State level, these indexes are 0.71 and 0.77 , respectively. Agriculture and forestry are dominant land uses, comprising the bulk of economic activity. Most agricultural and forest lands are under ejido tenure regimes. At the State level, Chignahuapan accounts for $45 \%$ of total timber harvests, while Zacatlan contributes another $9 \%$. Combined, the two municipalities support over half of the forest sector, including many jobs.

Tab. 1 - Wood density of timber species in the municipalities of Chignahuapan and Zacatlan, Puebla (Sources: Goche et al. 2000, Honorato \& Fuentes 2001, CONAFOR 2011, Arredondo \& Návar 2012).

\begin{tabular}{lc}
\hline Species & Density $\mathbf{( \mathbf { k ~ ~ } ^ { - 3 } )}$ \\
\hline Abies religiosa & 380 \\
Broadleaf species & 600 \\
Pinus pseudostrobus & 550 \\
Pinus patula & 430 \\
Pinus ayacahuite & 340 \\
Pinus montezumae & 460 \\
Pinus hartwegii & 496 \\
Pinus leiophylla & 485 \\
Pinus teocote & 480 \\
Pinus rudis & 530 \\
Quercus spp. & 760 \\
\hline
\end{tabular}

Timber harvests in the study area were prohibited by federal law from 1947 to 1975. The policy was intended to limit deforestation and protect important environmental functions. Unfortunately, in the absence of management, deforestation rates increased, although data for the region from that era are lacking. After 1975, forests were managed under two systems to meet multiple use objectives including timber production: the "Mexican Method of Forest Regulation" (MMOM), and the "Method for Silvicultural Development" (MDS - SMRN 2007). Management led to reduced deforestation rates, estimated at around 3.3\% per year today (for comparison, deforestation at the country level is $0.24 \%$ per year). Deforestation pressures are greatest near existing settlements, where forests are cleared for agriculture and residential use.

\section{Determining carbon sequestration}

Above-ground carbon sequestration in the forests of the study area was determined using forest inventory data from lands with forest management programs, avoiding the need for primary data or destructive sampling (Masera et al. 2000, Ordoñez \& Masera 2001, Fonseca et al. 2009). Inventory data on 24 and 28 Chignahuapan and Zacatlan forest lands covering an area of 20,187 and 6,124 ha, respectively, was collected. Most lands were covered by pine forests dominated by Pinus patula, although forests included sacred fir (Abies religiosa), mixed pine-oak (Pinus spp. Quercus spp.), and oak forests.

Following the documentary and spatial identification of forest types, the carbon in the above-ground biomass was calculated as follows (Masera et al. 2000 - eqn. 1):

$$
C_{A B}=V \cdot W D \cdot B E F \cdot C F
$$

where $C_{\mathrm{AB}}$ is the carbon content in aboveground biomass $\left(\mathrm{Kg} \mathrm{CO} \mathrm{CO}_{2} \mathrm{ha}^{-1}\right) ; V$ is the wood volume $\left(\mathrm{m}^{3} \mathrm{ha}^{-1}\right) ; W D$ is the wood density $\left(\mathrm{Kg} \mathrm{m}^{-3}\right) ; B E F$ is the biomass expansion factor; and $C F$ is the carbon fraction.

Eqn. 1 is conservative in its estimates of carbon because it only includes volume from tree species with marketable timber diameters, excluding aboveground biomass from unmerchantable species, trees with diameters less than $15 \mathrm{~cm} \mathrm{DBH}$, brushwood, and foliage (Di Matteo et al. 2014). Other important forest compartments not considered include deadwood, litterfall, below-ground plant biomass and soil carbon (Weggler et al. 2012, Ruiz-Peinado et al. 2013).

The expansion factor, $B E F$, was used to represent biomass components that were difficult to obtain from direct measurement (e.g., branches and leaves). The $B E F$ reference values, based on previous studies by Caballero et al. (2007) and Silva \& Návar (2010), were as follows: Pinus spp. (1.38), Quercus spp. (1.5), Abies spp. (1.3), and broadleaf species (1.3). Wood density $(W D)$ for each species in eqn. 1 was obtained from a variety of sources reported in Tab. 1 (i.e., Goche et al. 2000, Honorato \& Fuentes 2001, CONAFOR 2011, Arredondo \& Návar 2012).

As the dry weight of carbon in biomass ranges from 0.45 to 0.55 (IPCC 1996), our research used a mid-range value of carbon fraction $(C F)$ of 0.50 (Houghton et al. 1999). However, this default value could underestimate the overall carbon fraction (Jones \& O'Hara 2012). Finally, carbon values were then converted to $\mathrm{CO}_{2}$ using the conversion factor (44/12). Once aboveground biomass by species was established, it was expressed as carbon units per hectare by municipality using Microsoft Office Excel $^{\otimes}$.

The $\mathrm{Mg} \mathrm{CO}$ database was joined to the polygon database of forest lands using the Join command in $\operatorname{ArcGIS}^{\oplus}$ ver. 9.3; it was deployed in ArcGis ArcMap ${ }^{\mathrm{TM}}$ ver. 9.3 and interpolated to the total forest area of Chignahuapan (29,401 ha) and Zacatlan (28,039 ha) using the Kriging method ( Murillo et al. 2012). The magnitude of the stored carbon was categorized into three intervals or classes using the Reclassify command located in the Spatial Analyst module within ArcGis ver. 9.3. The final product was a map with average carbon sequestration categories: (1) high (from 218 to $531 \mathrm{Mg} \mathrm{CO}_{2} \mathrm{ha}^{-1}$ ); (2) medium (from 96 to $218 \mathrm{Mg} \mathrm{CO}_{2} \mathrm{ha}^{-1}$ ); and (3) low (from o to 96 $\left.\mathrm{Mg} \mathrm{CO} \mathrm{Ca}^{-1}\right)$. These categories were established according to the data distribution without using thresholds criteria.

\section{Estimating risk of deforestation}

A probabilistic model of land use (eqn. 2) was used to estimate deforestation risk (dependent variable) based on 21 socioeconomic and biophysical variables (independent variables, see Tab. S1 in Supplementary material - González 2000, Montgomery 2004). These variables were selected based on their importance as drivers of land use change between 1986 and 2011 in the study area (Cruz-Huerta et al. 2015 eqn. 2):

$$
\hat{Y}_{i}=\frac{1}{1+e^{-\left(\hat{\beta}_{0}+\hat{\beta}_{1} X_{1}+\hat{\beta}_{2} X_{2}+\ldots+\hat{\beta_{21} X_{21}}\right)}}
$$

where $\hat{Y}_{\mathrm{i}}$ is the probability that a hectare $(100 \times 100 \mathrm{~m})$ changes from forest use to another use; $i$ = forest, agriculture, livestock or residential use; $e$ is the base of the natural logarithm; $\beta_{0}, \beta_{\mathrm{i}}$ are intercept and estimators of the independent variables $\left(x_{\mathrm{i}}\right)$; and $X_{\mathrm{i}}$ are independent variables $\left(X_{1}\right.$, $\left.X_{2}, \ldots, X_{21}\right)$.

The stepwise procedure of SAS ${ }^{\circledR}$ ver. 9.0 was used to construct the model. Once the probabilistic model was specified, it was used to estimate (in maps) the probabilities of land-use changes for the forest area of 2011 in each municipality. 
Identification and comparative analysis of priority conservation areas for carbon sequestration

Priority areas for carbon sequestration were identified using the map algebra technique of the Spatial Analyst module and the Raster Calculator tool (Vargas et al. 2009). This technique allows calculating scenarios from two combined criteria. For example, a high-priority $\mathrm{CO}_{2}$ conservation area results from combining an area that has high carbon sequestration and a high risk of deforestation. The normalized criteria for carbon sequestration were: (1) high (from 0.66 to 1); (2) medium (from 0.33 to 0.66 ); and (3) low (from 0 to 0.33). The same classes were used for categorizing deforestation risk (CORENA 2000, CruzHuerta et al. 2015), although remote areas without risk of deforestation were not considered in the model. Tab. 2 shows the different combinations obtained.

Finally, a comparative spatial analysis was conducted on deforestation risk area, carbon sequestration, and priority conservation areas for carbon sequestration in order to provide a quantitative overview for resource planners in our two study area municipalities.

\section{Results and discussion}

\section{Estimating above-ground carbon} sequestration

The municipality of Chignahuapan had $\mathrm{CO}_{2}$ sequestration estimates ranging from $14 \mathrm{Mg} \mathrm{ha}^{-1}$ to $410 \mathrm{Mg} \mathrm{ha}^{-1}$. The highest estimates were found in areas with oak forests (Quercus spp.), not because they capture more carbon, but rather because of selective silvicultural practices (e.g., harvesting, thinning, etc.) in pine stands that decreased carbon content. While some authors suggest that carbon sequestration is mainly a function of forest composition and age (Ruiz-Peinado et al. 2013), we found no direct correlation $(r=0.049)$ between carbon sequestration and species richness (Tab. S2 in Supplementary material). This suggests that in our study area, carbon sequestration is dependent on tree age, size and volume rather than species. In Zacatlan, forests presented $\mathrm{CO}_{2}$ sequestration estimates ranging from $41 \mathrm{Mg}^{-{ }^{-1}}$ to $531 \mathrm{Mg} \mathrm{ha}^{-1}$, with an average of $158 \mathrm{Mg}$ $\mathrm{CO}_{2}$ ha $^{-1}$ and standard deviation of 8.7 (Tab.

Tab. 2 - Prioritization matrix of deforestation risk, carbon, and conservation. Risk of deforestation: high (from 0.66 to 1), medium (from 0.33 to 0.66 ), and low (from o to 0.33); Current carbon sequestration: high (from 218 to $531 \mathrm{Mg} \mathrm{CO}_{2}$ ha'), medium (from 96 to $218 \mathrm{Mg} \mathrm{CO}_{2} \mathrm{ha}^{-1}$ ), and low (from o to $96 \mathrm{Mg} \mathrm{CO}_{2} \mathrm{ha}^{-1}$ ). ( $¥$ ): Conservation areas priority is derived from the risk of deforestation and current carbon sequestration levels.

\begin{tabular}{ccc}
\hline $\begin{array}{c}\text { Risk of } \\
\text { deforestation }\end{array}$ & $\begin{array}{c}\text { Current carbon } \\
\text { sequestration }\end{array}$ & $\begin{array}{c}\text { Conservation areas } \\
\text { priority }\end{array}$ \\
\hline High & High & High \\
High & Medium & High \\
Medium & High & High \\
High & Low & Medium \\
Medium & Medium & Medium \\
Low & High & Medium \\
Medium & Low & Low \\
Low & Medium & Low \\
Low & Low & Low \\
\hline
\end{tabular}

S2). Once again, the correlation between carbon sequestered and the number of species per management unit (Tab. S2) was low $(r=0.02)$.

An earlier study by Castellanos et al. (1996) used a series of allometric equations to estimate that forests of Chignahuapan and Zacatlan store on average 81 to $150 \mathrm{Mg}$ $\mathrm{CO}_{2}$ ha $^{-1}$. Ruiz-Peinado et al. (2013) estimated the total carbon present in the unthinned, moderately thinned and heavily thinned plots in Mediterranean maritime pines obtaining 317,256 and $234 \mathrm{Mg} \mathrm{ha}^{-1}$, respectively, estimates consistent with our findings.

\section{Above-ground carbon sequestration}

In the municipality of Chignahuapan, there are 29,401 ha of forest area, of which 3,480 ha $(11.8 \%)$ were determined to have high carbon sequestrations suitability, i.e., current carbon sequestered from 218 to $531 \mathrm{Mg} \mathrm{CO}_{2}$ ha $^{-1}$ (Tab. 3, Fig. 1a). In contrast, $17.5 \%$ of the forested area $(5,157$ ha) held 96 to $218 \mathrm{Mg} \mathrm{CO}_{2}$ ha $^{-1}$ and was classified as medium. The balance $(70.6 \%$ or 20,764 ha of the total) was classified as low and held on average $82 \mathrm{MgCO}_{2} \mathrm{ha}^{-1}$. These results are consistent with previous research by Angeles et al. (2005) who found low carbon sequestration in forests with young trees and/or sparse vegetation, oftentimes as a result of harvesting activities (Fig. 1a).

In Zacatlan, Fig. 2 a shows that areas with high carbon sequestration are located in the north and center of the municipality, capturing around to $531 \mathrm{Mg} \mathrm{CO}_{2}$ ha $^{-1}$. These areas are covered by trees of the genera Pinus and Quercus. Species, age and density affect $\mathrm{CO}_{2}$ sequestration rates; however, earlier research by Castañeda et al. (2012) found that Quercus spp. forests stores on average $664 \mathrm{Mg} \mathrm{CO} \mathrm{Ca}^{-1}$. This finding that oak forests hold greater levels of carbon than pine forests is not surprising given the silvicultural regimes applied, where oaks are not intensively managed due to low commercial value. Areas with low sequestration averaged about $68 \mathrm{CO}_{2}$ $\mathrm{Mg} \mathrm{ha}{ }^{-1}$, while areas with medium sequestration captured $164 \mathrm{CO}_{2} \mathrm{Mg} \mathrm{ha}^{-1}$, based on a 50-year-old stand. Figueroa et al. (2010) found that on average a 25 -year-old stand of Pinus patula captures $86 \mathrm{CO}_{2} \mathrm{Mg} \mathrm{ha}{ }^{-1}$, which is similar to the values found in this study.

Based on our analysis, managed forests in Chignahuapan and Zacatlan can function efficiently as carbon sequestration lands (sinks), since $12 \%$ of the forest area is classified as high carbon sequestration and $73 \%$ as low-current carbon sequestration, ranging from $2.7 \mathrm{MgCO}_{2}$ ha $^{-1}$ to $164 \mathrm{MgCO}_{2}$ ha $^{-1}$ (Fig. 2a). Finally, although both municipalities include areas classified as high, medium and low current carbon sequestration, their current carbon levels exhibit a wide variation due to the structure, management and volume of present species (Tab. 3).

\section{Deforestation risk}

Deforestation risk in Chignahuapan and Zacatlan was determined by a probabilistic

Tab. 3 - Comparative data on current carbon sequestration, deforestation risk, and priority areas in the municipalities of Chignahuapan and Zacatlan, Puebla (Mexico). ( $¥)$ : Differences between risk of deforestation and priority for $\mathrm{CO}_{2}$ sequestration areas are due to the use of buffers in the processing and categorization of satellite images and the models. For example, remote areas without development pressure were not considered in the modeling.

\begin{tabular}{lrrrrrr}
\hline \multirow{2}{*}{ Criteria } & \multicolumn{2}{l}{$\begin{array}{l}\text { Chignahuapan Area } \\
\text { (ha and \%) }\end{array}$} & & \multicolumn{4}{l}{$\begin{array}{l}\text { Zacatlan Area } \\
\text { (ha and \%) }\end{array}$} \\
\cline { 2 - 7 } & \multicolumn{1}{l}{ High } & \multicolumn{1}{l}{ Medium } & \multicolumn{1}{l}{ Low } & \multicolumn{1}{l}{ High } & \multicolumn{1}{l}{ Medium } & Low \\
\hline $\mathrm{CO}_{2}$ sequestration & $3,480(11.8 \%)$ & $5,157(17.5 \%)$ & $20764(70.6 \%)$ & $3,188(11.4 \%)$ & $2,804(10.0 \%)$ & $22,045(78.6 \%)$ \\
Deforestation risk ${ }^{(\ddagger)}$ & $2,421(8.2 \%)$ & $4,585(15.6 \%)$ & $4740(16.1 \%)$ & $1,798(6.4 \%)$ & $2,271(8.1 \%)$ & $337(1.2 \%)$ \\
$\mathrm{CO}_{2}$ sequestration priority ${ }^{(\ddagger)}$ & $628(2.1 \%)$ & $2,876(9.8 \%)$ & $7183(24.4 \%)$ & $310(1.1 \%)$ & $1,744(6.2 \%)$ & $2,265(8.1 \%)$ \\
\hline Total forest area & & 29,401 & & & 28,039 & \\
\hline
\end{tabular}



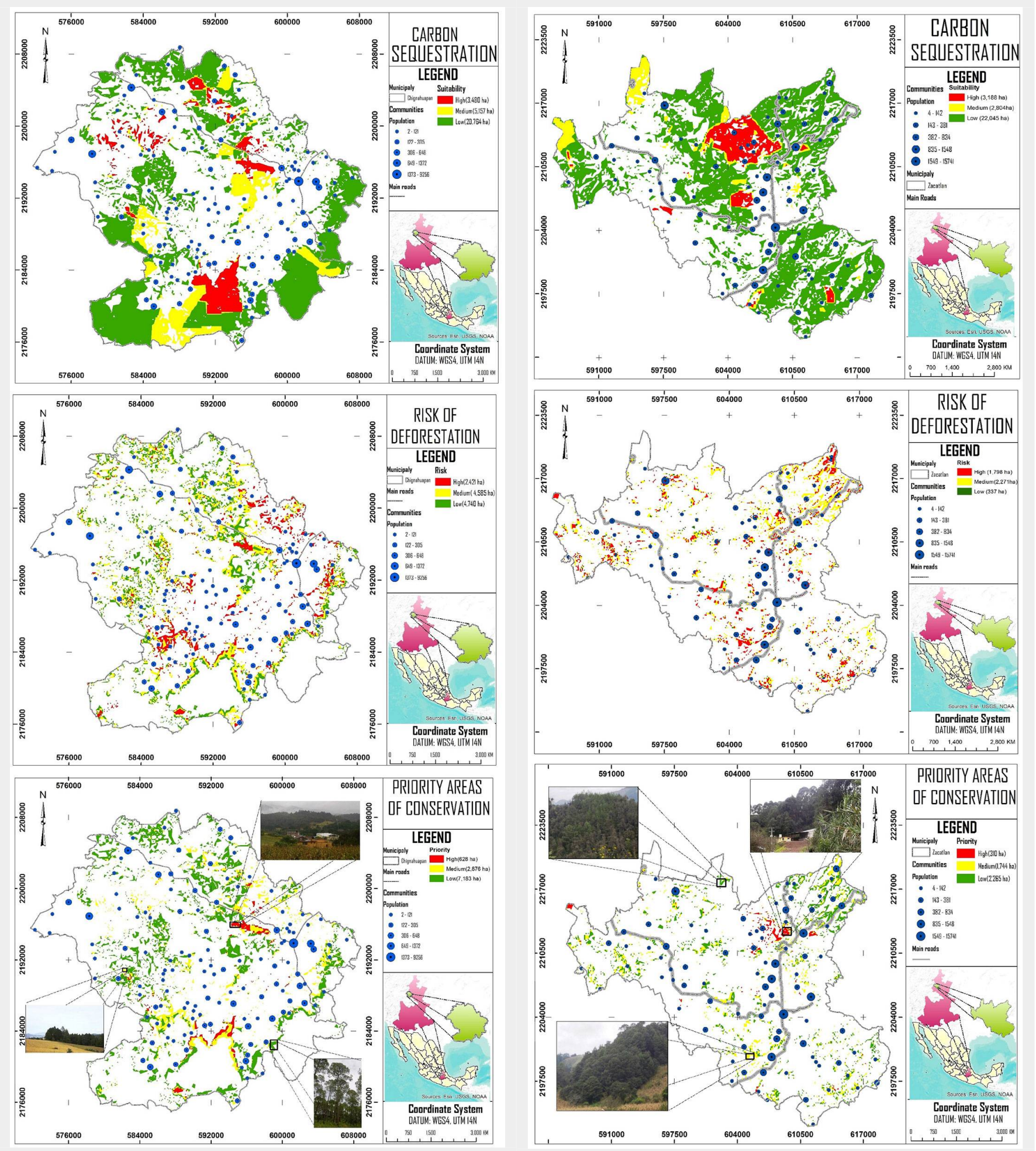

Fig. 1 - Above-ground $\mathrm{C}$ sequestration $\left(\mathrm{CO}_{2} \mathrm{Mg}_{\mathrm{ga}}{ }^{-1}\right.$ - top), deforestation risk (middle), and priority conservation areas (bottom) for above-ground carbon sequestration in the municipality of Chignahuapan, Puebla (Mexico).

Fig. 2 - Above-ground $\mathrm{C}$ sequestration ( $\mathrm{CO}_{2} \mathrm{Mg}_{\text {ha }}{ }^{-1}$ - top), deforestation risk (middle), and priority conservation areas (bottom) for above-ground carbon sequestration in the municipality of Zacatlan, Puebla (Mexico).

model of land-use change. The model for Zacatlan included 21 significant variables $(p \leq 0.05)$, while Chignahuapan included 16 significant variables. Discarded variables included: population density, distance to trails, distance to low marginalization, and land tenure. It is important to note that within the two models, the independent variables have different relative impor- tance, though for both municipalities the ance inflation factors $<10$. As a conseminimum distance to agricultural areas (+), quence, there is no linear relationship beelevation (-), and slope (-) had the greatest tween the model's independent variables impact on deforestation (Tab. S1 in Supple- (Kutner et al. 2005). The adj- $R^{2}$ presented mentary material).

There was no correlation between independent variables in the deforestation risk model, nor was the model affected by multicollinearity, having tolerances $>1$ and variin the model was $>20 \%$, which indicates a low amount of variance explained. However, on average, about $80 \%$ concordant observations were obtained by the model (Tab. 4), indicating that the independent 
and dependent variables are ordered in the same direction; therefore, the model is appropriate for predicting the phenomenon of interest (Gomben et al. 2012). Moreover, due to the broad inclusion of both biophysical and socioeconomic variables, we deemed the model's goodness-of-fit as adequate.

The map of deforestation risk for Chignahuapan (Fig. 1b) shows that $8.2 \%$ (2421 ha) of the total forest area $(29,401 \mathrm{ha})$ in the municipality is at high risk of deforestation; these areas border agricultural and livestock areas (Fig. 1b). Also, 15.6\% (4585 ha) of the total forest area was found to have medium risk, and just $16.1 \%$ (4740 ha) is at low risk. In Zacatlan, 1798, 2271 and 337 ha were assessed to be at high, medium and low risk of deforestation, respectively (Fig. $2 b$ ). The greatest deforestation threats are due to the conversion from forest to agriculture (forest-agriculture), grazing (forestlivestock), and development (forest-residential - Cruz-Huerta et al. 2015).

High-risk deforestation areas are located in the northwestern part of the municipality, while medium-risk areas are distributed throughout the municipality (Fig. 2b). In contrast, low-risk areas are located in the northern part of the municipality. This is likely due to forest fragmentation from agriculture and livestock activities, which increases the risk of increasing deforestation in the municipality. Finally, it is important to note that wildfire is a limited risk on managed forests within each municipality.

\section{Priority areas for above-ground carbon sequestration}

We integrated current carbon sequestration and deforestation risk to determine priority areas for conservation efforts (see Tab. 2). For Chignahuapan, we identified 628,2876 and 7183 ha with high, medium and low conservation priority, respectively (Fig. 1C). Low-priority areas tended to be located in remote forest zones with little disturbance, while medium-priority areas were located near agricultural limits. Highpriority areas are located in forest zones situated near livestock pasture, agricultural lands, and residential settlements. Our finding that the largest forest area is classified as having low conservation priority for carbon sequestration may be due in part to sound management practices by forest managers and their efforts to preserve healthy forests that provide sustained flows of environmental goods and services (SMRN 2007). As a result, both deforestation risk and current carbon sequestration are low or medium, largely due to periodic harvests which have reduced biomass levels.

In Zacatlan, 310, 1744 and 2265 ha were identified as high, medium and low conservation priority for carbon sequestration, respectively (Fig. 2C). These lands, distributed throughout the municipality, represent land areas that are roughly half in size of what we found in Chignahuapan (Fig. 1C).

Tab. 4 - Measures of association of predicted probabilities and observed responses for the deforestation risk model for both municipalities. (VIF): Variance inflation factor.

\begin{tabular}{llcc}
\hline \multirow{2}{*}{ Variable } & Parameter/ & \multicolumn{2}{c}{ Municipality } \\
\cline { 3 - 4 } & Index & Chignahuapan & Zacatlan \\
\hline Measures of & Concordant & 85.9 & 76.3 \\
association & Discordant & 13.2 & 22.9 \\
& Bound & 0.9 & 0.8 \\
\hline Pairs & - & $75,418,437$ & $94,900,581$ \\
\hline Correlation indices & Somers' D & 0.72 & 0.53 \\
& Gamma & 0.73 & 0.53 \\
& Tau-a & 0.16 & 0.15 \\
& C & 0.86 & 0.76 \\
\hline Adj-R ${ }^{2}$ (\%) & - & 37.33 & 20.12 \\
\hline Multicollinearity & Tolerance & 0.63 & 0.8 \\
& VIF & 1.6 & 1.25 \\
\hline
\end{tabular}

Integrating current carbon sequestration and deforestation risk to identify conservation priority areas (Tab. 3) identified Chignahuapan as a focal region for conservation. This is due in part because forests in the municipality are at greater risk of deforestation due to high population densities for agricultural, livestock and residential uses to meet food, clothing, housing and future energy needs. For example, the population density (residents ha ${ }^{-1}$ ) for Chignahuapan and Zacatlan in the agricultural, livestock and residential areas was 1.1, 90.3, 70.8 in 1985 and rose up to $4.5,11.6,327.5$ in 2010, respectively. Zacatlan's population density is more than four times that of Chignahuapan, with the population of the former more concentrated (CONAPO 2010).

By analyzing the forest carbon sequestration data in relation to the total forest area of the two municipalities, the results were found to be very similar because stands under forest use were analyzed. However, areas with high conservation priority for carbon sequestration in the municipality of Chignahuapan occupy 628 ha, representing $2 \%$ of the forest area of the municipality (Tab. 3). For comparison, Zacatlan has 310 ha identified as high priority, accounting for only $1 \%$ of the forest area.

The high, medium and low conservation priority categories for different forest management units were validated through field trips and consultation with Technical Forest Service Providers. Some authors agree that validating priority conservation areas requires considering specific mapping points and then undertaking field visits (Lasso et al. 2011). Our field verification and consultation with forest managers revealed that our high-priority conservation areas have a high probability of deforestation since they are surrounded by agricultural and livestock areas, as well as small patches of urban areas. In fact, areas with high conservation priority for carbon sequestration were located in forest clusters with mature trees, fragmentation by agricultural areas with corn crops, livestock areas, and urban areas, which are all indica- tors of high carbon sequestration and high deforestation risk. Areas identified for medium conservation priority were typically pine-oak forest, with small patches of farmland within the forest area. Finally, low-priority areas showed little fragmentation by any land use. These areas were generally located away from the agricultural frontiers, or were located in managed forest areas.

\section{Conservation strategies for priority} areas

The identification and management of priority conservation areas must consider economic, social and environmental factors to ensure sustainability (Sánchez et al. 2008). Tab. S3 (Supplementary material) outlines some key management strategies and responsible implementing agencies for the study area. The development of management strategies at different administrative and geographic levels has been considered to foster efficiency in conservation programs and actions, seeking to obtain maximum impact with the resources available in the study area (Kristensen \& Rader 2001, March et al. 2009).

Future studies should focus on a thorough quantification of both above- and below-ground carbon components in order to better determine total carbon sequestration and how these levels are affected by various forest management regimes. To better understand deforestation risk, we suggest the development of a series of future scenarios of land use change. These could serve as the basis for analyzing the impacts and opportunity costs of carbon sequestration and other ecosystem services. For priority carbon areas, we recommend to test various forest management practices designed to both protect stored forest carbon and facilitate future carbon sequestration at the forest level. These practices should carefully consider both conservation and management goals, seeking to provide a blueprint for mitigating climate change impacts on Mexico's forest resources. 


\section{Conclusions}

We estimated above-ground carbon sequestration in forests of Chignahuapan and Zacatlan municipalities, Puebla (Mexico) using volume information from forest management programs and the kriging interpolation method. Our results showed that both municipalities have similar current carbon sequestration, with carbon estimates ranging from 14 to $531 \mathrm{Mg} \mathrm{CO}_{2} \mathrm{ha}^{-1}$. Based on this, we classified areas as high current carbon sequestration (218 to 531 $\mathrm{Mg} \mathrm{CO}_{2}$ ha-1), medium (96 to $218 \mathrm{Mg} \mathrm{CO}_{2}$ ha 1), and low sequestration (from o to $96 \mathrm{Mg}$ $\mathrm{CO}_{2} h^{-1}$ ). Next, we applied a probabilistic model of land use in order to identify future risk of deforestation based on a host of socioeconomic and biophysical variables. Combining current carbon sequestration with deforestation risk allowed to identify priority lands for conservation. In Chignahuapan and Zacatlan, 628 and 310 ha, respectively, were determined to have high priority for carbon sequestration.

It is important to note that in this study the potential of forests to sequester additional carbon in the future was not considered. For example, a young forest on a productive site may have little stored carbon today, but may sequester large quantities in the future. In contrast, an older stand comprised of many large trees may have high levels of stored carbon, but may not store much additional carbon in the future as stand growth slows. In fact, age -or density-induced mortality could transition the stand into a net carbon emitter as large trees die and decompose.

Despite this, the approach developed here represents an important first-step in identifying priority conservation areas through the integrated assessment of carbon sequestration and deforestation risk. This knowledge can enhance efforts to efficiently target land management strategies aimed to mitigate climate change impacts. In doing so, the approach can serve as a model for other forested regions in Mexico and other countries.

\section{Acknowledgments}

We thank the Colegio de Postgraduados for funding this study under Priority Research Line 1 (LPI1): Sustainable Management of Natural Resources. We also thank Dr. Robert J. Lilieholm and Dr. H.M. de los Santos-Posadas for technical review and statistical support.

\section{References}

Alvarez S, Rubio A (2013). Carbon baseline in a mixed pine-oak forest in the Juarez mountain range (Oaxaca, Mexico) using the $\mathrm{CO}_{2} \mathrm{FIX} \mathrm{V.3.2}$ model. Revista Chapingo serie Ciencias Forestales y del Ambiente 19: 125-137. - doi: 10.5154/ r.rchscfa.2012.01.005

Angeles G, Valdez JR, De Los Santos HM, Hernández P, Gómez A, Velázquez A (2005). Carbon storage in managed Pinus patula forests in central Mexico. International Forestry Review 7: 294.
Arredondo FM, Návar JJ (2012). Estimating bole wood specific gravity in trees of temperate forest communities of northern Durango, Mexico. Madera y Bosque 18: 77-88. - doi: 10.21829/myb. 2012.1811139

Boden TA, Marland G, Andres RJ (2017). Global, regional, and national fossil-fuel $\mathrm{CO}_{2}$ emissions. Carbon Dioxide Information Analysis Center, Oak Ridge National Laboratory, US Department of Energy, Oak Ridge, Tennessee, USA. - doi: 10.3334/CDIAC/00001 V2017

Caballero M, Lozano S, Ortega B (2007). Efecto invernadero, calentamiento global y cambio climático: una perspectiva desde las ciencias de la tierra [Greenhouse effect, global warming, and climate change: a perspective from the earth sciences]. Revista digital universitaria UNAM 8: 1-12. [in Spanish] [online] URL: http:// www.revista.unam.mx/

Cantú C, Scott JM, Wright RG (2004). The Gap Analysis Program on the assessment of nature reserves of Mexico. Gap Analysis Bulletin 10: 811.

Castañeda JC, Gallegos AR, Sánchez M, Domínguez PA (2012). Biomasa aérea y posibles emisiones de $\mathrm{CO}_{2}$ después de un incendio; caso del bosque "La Primavera", Jalisco, México [Aerial biomass and possible $\mathrm{CO}_{2}$ emissions after a fire: Case of the forest "la primavera", Jalisco, Mexico]. Ra Ximhia, Sociedad, Cultura y Desarrollo 1: 1-15. [in Spanish]

Castellanos JF, Velázquez A, Vargas J, Rodríguez C, Fierros AM (1996). Biomass production of a Pinus patula stand. Agrociencia 30: 123-128.

Collins G, Steiner FR, Rushman MJ (2001). Landuse suitability analysis in the United States: historical development and promising technological achievements. Environmental Management 28: 611-621. - doi: 10.1007/s002670010247 CONAFOR (2011). Consideraciones tecnológicas en la protección de la madera [Technological considerations in timber protection]. Comisión Nacional Forestal, Universidad Michoacana de San Nicolás de Hidalgo, Morelia, Michoacán, Mexico, pp. 50. [in Spanish]

CONAFOR (2014). Estrategia Nacional para REDD+ (ENAREDD+) [National strategy for REDD+ (ENAREDD+)] Comisión Nacional Forestal, CONAFOR, Mexico, pp. 117. [in Spanish] [online] URL: http://www.enaredd.gob.mx/wpcontent/uploads/2015/08/Estrategia-Nacionalpara-REDD.pdf

CONAPO (2010). Indice de marginación por entidad federativa y municipio [Marginalization index by state and municipality]. Consejo Nacional de Población - CONAPO, Mexico, DF, pp. 332. [in Spanish] [online] URL: http://www. conapo.gob.mx/es/CONAPO/Indice_de_margin acion_urbana_2010

CORENA (2000). Actualización del programa de ordenamiento ecológico del Distrito Federal [Ecological management program update of the Distrito Federal]. Comisión de Recursos Naturales, SEDEMA-CORENA, México City, Mexico, pp. 133. [in Spanish]

Cruz-Huerta C, González-Guillén MJ, MartínezTrinidad T, Escalona-Maurice MJ (2015). Modeling land-use change and future deforestation in two spatial scales. Revista Chapingo Serie Ciencias Forestales y del Ambiente 21 (2): 137-156. doi: 10.5154/r.rchscfa.2014.06.025
Di Matteo G, Tunno I, Nardi P, De Angelis P, Bertini G, Fabbio G (2014). C and N concentrations in different compartments of outgrown oak coppice forests under different site conditions in Central Italy. Annals of Forest Science 71: 885-895. - doi: 10.1007/s13595-014-0390-4 Figueroa CM, Angeles G, Velázquez A, De Los Santos HM (2010). Biomass estimation in a managed Pinus patula Schl. et Cham. forest at Zacualtipan, Hidalgo State. Revista Mexicana de Ciencias Forestales 1: 105-112.

Fonseca W, Alice F, Rey JM (2009). Models for biomass estimation in native forest tree plantations and secondary forests in the Costa Rican Caribbean Region. Bosque 30: 36-47. - doi: 10.4067/S0717-92002009000100006

García MA, Lagares N (2011). Zonas prioritarias o acciones prioritarias? Desde que perspectiva una zona prioritaria lo es para cualquier tipo de acción de ayuda al desarrollo [Priority areas or priority actions? From what perspective is it a priority area for any action of development aid]. Facultad de Ciencias Políticas y Sociales, Universidad de Santiago de Compostela, X Congreso AECPA, Spain, pp. 33. [in Spanish]

Goche JR, Fuentes M, Borja A, Ramírez H (2000). Variation in physical properties of Abies religiosa and Pinus ayacahuite var. veitchii wood. Revista Chapingo serie Ciencias Forestales y del Ambiente 6: 83-92.

Gomben P, Lilieholm R, Gonzalez-Guillen M (2012). Impact of demographic trends on future development patterns and the loss of open space in the California Mojave Desert. Environmental Management 49: 305-324. - doi: 10.1007/ soo267-011-9749-6

González MJ (2000). Future scenarios of land use in the California Mojave Desert. PhD Thesis, Utah State University, Logan, UT, USA, pp. 163. Greenpeace Mexico (2010). México ante el cambio climático: evidencias, impactos, vulnerabilidad y adaptación [Mexico on cimate change: evidence, impacts, vulnerability and adaptation]. Greenpeace, Mexico, pp. 72. [in Spanish] [online] URL: http://www.greenpeace.org/mex ico/Global/mexico/report/2010/6/vulnerabilidadmexico.pdf

Honorato JA, Fuentes ME (2001). Propiedades físico- mecánicas de la madera de cinco especies de encino del estado de Guanajuato [Physical and mechanical properties of five oak species of Guanajuato]. Revista Ciencia Forestal en México 26: 5-28. [in Spanish]

Houghton A, Hackler JL, Lawrence KT (1999). The US carbon budget: contributions from land-use change. Science 285: 574-577. - doi: 10.1126/science.285.5427.574

IICA (2012). Potencial de servicios ambientales en la propiedad social en México [Potential of environmental services in public ownership in Mexico]. Instituto Interamericano de Cooperación para la agricultura, IICA, Mexico, pp. 103. [in Spanish]

INEGI (1999). Cartas topográficas escala 1:50000 [Topographic maps at 1:50000] (E14B13-E14B14E14B15-E14B23-E14B24-E14B25-E14B33-E14B34E14B35-F14D83-F14D84-F14D85). Instituto Nacional de Estadística Geografía e Informática, INEGI, Aguascalientes, Ags, Mexico, pp. 12. [in Spanish]

INEGI (2010a). Conteo de la población y vivienda 
[Population and housing census]. Base de datos digital, Instituto Nacional de Estadística Geografía e Informática - INEGI, Mexico. [in Spanish] [online] URL: http://www.inegi.org. $\mathrm{mx} /$

INEGI (2010b). Conteo de la población y vivienda [Population and housing census]. Base de datos digital del periodo 1985-2010. Instituto Nacional de Estadística Geografía e Informática - INEGI, Mexico [online] URL: http://www.inegi. org.mx/

INEGI (2013). Mapa digital de México v5.0 (Tenencia de la tierra) [Digital map of Mexico (Land tenure)]. Instituto Nacional de Estadística Geografía e Informática - INEGI, Mexico, pp. 1. [in Spanish] [online] URL: http://gaia. inegi.org.mx/mdm5/viewer.html

IPCC (1996). Guidelines for national greenhouse gas inventories. IPCC Meteorological Office, Intergovernmental Panel on Climate Change, Bracknell, UK, pp. 113. [online] URL: http:// www.ipccnggip.iges.or.jp/public/gl/invs1.html Jones DA, O'Hara K (2012). Carbon density in managed coast redwood stands: implications for forest carbon estimation. Forestry 85: 99110. - doi: 10.1093/forestry/cpro63

Kristensen PJ, Rader CJ (2001). The strategic management approach: practical planning for development managers. Conservation International, Washington, DC, USA, pp. 162.

Kutner MH, Nachtsheim CJ, Neter J, Li W (2005). Applied linear statistical models $\left(5^{\text {th }}\right.$ edn). McGraw-Hill, New York, USA, pp. 1396.

Lasso A, Rial A, Matallana CL, Ramírez W, Señaris CS, Díaz A, Corzo G, Machado A (2011). Biodiversidad de la cuenca del Orinoco. Áreas prioritarias para la conservación y uso sostenible [Biodiversity of the Orinoco Basin. Priority areas for conservation and sustainable use]. Instituto de Investigación de Recursos Biológicos Alexander von Humboldt, Colombia, pp. 304. [in Spanish]

March IJ, Carvajal MA, Vidal RM, Eivin J, Ruiz G (2009). Planificación y desarrollo de estrategias para la conservación de la biodiversidad en Capital natural de México [Planning and development of strategies for the conservation of biodiversity in Mexico's natural capital]. vol. II: Estado de Conservación y tendencias de Cambio. CONABIO, Mexico, 545-573 pp. [in Spanish] Masera O, De Jong B, Ricalde I (2000). Consolidación de la oficina mexicana para la mitigación de gases de efecto invernadero [Consolidation of the Mexican Office for the mitigation of greenhouse gases]. Instituto de Ecología, Universidad Nacional Autónoma de México-ECOSUR, Mexico, pp. 197. [in Spanish]

Montgomery C (2004). Diseño y análisis de experimentos [Design and analysis of experiments]. Edit. Limusa, DF, Mexico, pp. 686. [in Spanish]

Morgan L, Maxwell S, Tsao F, Wilkinson AC, Etnoyer $\mathrm{P}$ (2005). Marine priority conservation areas: Baja California to the Bering Sea. Commission for Environmental Cooperation of North America and the Marine Conservation Biology Institute, Montreal, Canada, pp. 125.

Murillo D, Ortega I, Carrillo JD, Pardo A, Rendón $J$ (2012). A comparison of interpolation methods for creating noise maps in urban environments. Ingenierías USB Med 1: 62-68.

Ordoñez JA, Masera O (2001). Captura de carbono ante el cambio climático [Carbon sequestration to mitigate climate change]. Madera y Bosques 7: 3-12. [in Spanish] - doi: 10.21829/ myb.2001.711314

Riemann H, Ezcurra E (2005). Plant endemism and natural protected areas in the Peninsula of Baja California, Mexico. Biological Conservation 122: 141-150. - doi: 10.1016/j.biocon.2004.07.008 Ruiz-Peinado R, Bravo-Oviedo A, López-Senespleda E, Montero G, Río M (2013). Do thinnings influence biomass and soil carbon stocks in Mediterranean maritime pinewoods? European Journal of Forest Research 132: 253-262. - doi: 10.1007/s10342-012-0672-z

Saavedra Z, Ojeda L, López RF (2011). Identification of threatened areas of environmental value in the conservation area of Mexico City and setting priorities for their protection. Investigaciones Geográficas 74: 19-34.

Silva FM, Návar JJ (2010). Biomass expansion factors in temperate forest communities of north Durango. Revista Mexicana de Ciencias
Forestales 1: 55-62.

SMRN (2007). Diagnóstico socioeconómico y de manejo forestal unidad de manejo forestal, Zacatlan [Socioeconomic and forest management diagnostic at the forest management unit, Zacatlan]. Secretaria del Medio Ambiente y Recursos Naturales, Asociación Regional de Silvicultores Chignahuapan - Zacatlan, AC Puebla, Mexico, pp. 281. [in Spanish]

Sánchez $\mathrm{V}$, Illoldi $\mathrm{P}$, Linaje $\mathrm{M}$, Fuller $\mathrm{T}$, Sarkar $\mathrm{S}$ (2008). Por qué hay un costo en posponer la conservación de la diversidad biológica en México? [Why is there a cost to postpone the conservation of biodiversity in Mexico?]. Biodiversitas 76: 7-12. [in Spanish]

Vargas GA, Aguilar S, Castillo MA, Esquivel MA, Hernández MA, López AM, Quechulpa S (2009). Programa estatal para la compensación por servicios ecosistémicos [State program for compensation for ecosystem services]. Comisión Nacional para el Conocimiento y Uso de la Biodiversidad, Mexico, pp. 58. [in Spanish]

Weggler $K$, Dobbertin $M$, Jungling $E$, Thurig $E$ (2012). Dead wood volume to dead wood carbon: the issue of conversion factors. European Journal of Forest Research 131: 1423-1438. - doi: 10.1007/s10342-012-0610-0

\section{Supplementary Material}

Tab. S1 - Dependent and independent variables included in the deforestation risk probabilistic model.

Tab. S2 - Relationship between carbon content and the number of existing species per forest management unit and municipality.

Tab. S3 - Management strategies for the protection of priority conservation areas for carbon sequestration and responsible Agencies and Partners to apply them.

Link: Cruz-Huerta_1980@supplo01.pdf 